\title{
On Enhancing the Sense of Civic Social Responsibility of Minority College Students in the Course of Situation and Policy
}

\section{Mingjing Yin}

Nanchang Institute of Science \&Technology, Nanchang, 330108,China

Keywords: Situation and policy; minority college students; sense of civic social responsibility

\begin{abstract}
The course of situation and policy is the main channel of ideological and political education of minority college students, the course of situation and policy tells minority college students how to effectively carry out the citizen's sense of social responsibility, it improves minority college students' civic awareness and quality, fosters minority college students' citizen subjectivity, shapes their citizen character, formation their civic virtue.
\end{abstract}

\section{What minority college students' sense of social responsibility is.}

In today's world, political and economic situation of national cultural conflict the winds of change, mutual penetration of western values is dressed in a beautiful coat in a variety of other countries in the world strong promotion, which puts forward higher requirements on minority college students' insight and their analysis, so minority college students must know what the world situation and policy is. Therefore, in order to help minority college students understand the situation and tasks faced by the party and the country in a comprehensive and correct manner, the international and domestic situations should be taken into consideration. The sense of responsibility in civil society is a strong sense of self-consciousness or lofty emotion that every citizen should take responsibility for himself, others, collectives, society and the state. The sense of responsibility of civil society is the foundation and starting point of all virtues. It is the embodiment of civic rationality and conscience, and it also the important sign of the maturity and perfection of minority college students. Citizen social responsibility is based on moral responsibility, and civil responsibility of cultural history and basic content bases generation including civil society consciousness, citizen moral emotion, moral will, citizen dedication the organic unity.

The survival and development of people which assumes social responsibility as the premise, there is no citizen social responsibility, any person, any society can not exist and develop, the situation and policy course can enhance minority college students' thinking ability as the current social problems and the development of social responsibility to be the spirit of the main position.

Although universities have stressed that importance of civic social responsibility of minority college students, which is a profound understanding of the spirit of civic social responsibility of minority college students, in the actual operation process, the situation and policy is still being ignored, teaching quantity is reduced, each semester only spent 4 hours to complete the task of teaching, only spend a night time to complete without the situation and policy course.

\section{The content settings of minority college students' courses are lacking of civic responsibility.}

Contemporary minority college students are lack of the obligations of citizenship awareness, their citizenship behavior is relatively weak, there are some differences between college students' 
cognition and practice of citizens, the main reason is that lack of clear and civic education system in colleges and universities, especially in mountain areas, they attaches great importance to cultivate of Chinese traditional education professional skills, not pay attention to cultivate comprehensive quality the students' ideological and political sense, people combine to neglect the citizens of personality, ignores the citizens should have the consciousness of citizenship, thus some of people lack of country, society and others responsible consciousness, it should be aimed at the current international and domestic events occurred in a timely manner to the organization of teaching, students propaganda of the party and state policies. However, some university teaching programs are not updated according to current affairs, which can not provide help to students.

Most concerned about the hot issues, for students on the ideological and cognitive errors. It does not fully reflect the timeliness of the course, students focus on killing the enthusiasm of domestic and international affairs, docking training, it does not put forward a series of new ideas and new perspectives, the new judgment to enrich the teaching, teaching resources, teaching system is not perfect, lack of pertinence and timeliness of teaching.

\section{Classroom teachers' professional quality of minority college students is uneven.}

From the current view, minority college situation and policy class is mainly composed of teams of teachers: full-time teachers, part-time teachers, the mountain together to undertake the task of teaching the most common, therefore, the situation and policy course teachers level is uneven.

The difference between part-time teachers and full-time teachers is that part-time teachers often engaged in student work of counselors, or engaged in party and administrative work, they usually busy with affairs of specific management, lead time and energy shortage, some teachers just take teaching as a means of livelihood, lack of the concept of lifelong learning, with emphasis on the situation and policy class is not have enough classroom teaching, they often deal with troubles, and even some teachers do not see the figures, up to 2 hours of video throughout the whole class.

\section{Ways to strengthen the sense of civic responsibility of minority college students in the course of situation and policy.}

Highlight the awareness of the world and current affairs. Teaching of situation and policy is different from other college ideological and political theory course, it aims to guide and inspire the students the correct analysis of the situation at home and abroad, the future development trend of insight, profound understanding of the party and state policies; it focuses on improving minority college students' ability of policy training, thinking quality and the situation, minority college students have a strong patriotic enthusiasm, attention to social development and the progress of civilization, and the situation and policy course of the latest problem analysis and research, just to meet minority college students psychological novelty, empathy, and produce identity, training them to pay attention to the world, pay attention to the interest and awareness of current affairs, so as to improve their political quality.

\section{Cultivate the spirit of social responsibility.}

According to the above analysis, we believe that the following aspects should be strengthened to cultivate the sense of civil society responsibility of the situation and policy. Teaching content: integration of the situation and policy curriculum content, highlighting the social problems of college students, awareness and social responsibility to play the spirit. First, set the thematic content of civic education in the curriculum teaching, such as the role of learning, value of teaching, 
experiential learning, aesthetic education to create the overall atmosphere of teaching, to achieve the effect of education, highlighting the college students' social concern consciousness and social responsibility spirit. Second, pay attention to citizens' sense of social responsibility education integration and the social situation of policy, reform the teaching content of situation and policy should be to stimulate students' learning enthusiasm, improve the students' awareness of the curriculum as the starting point, the latest theoretical achievements of universities should increase the harmonious society, the eighteenth National Congress of the CPC proposed a series of new thought, new ideas and new conclusions to enrich teaching, to enrich teaching resources, improve teaching system; in addition, the universities not only should be combined with the current domestic and international situation, but also hot social focus problem for students to design scientific exploration of problem situations, organize students to discuss, to mobilize the enthusiasm of students, to participate in citizens the sense of social responsibility education process.

Teaching methods: combination of situation and policy, classroom teaching and practice teaching. On the one hand, colleges and universities should actively carry out campus activities, such as class meetings, exchange meetings, lecture sessions, campus cultural activities, and community activities and so on. On the other hand, colleges and universities should also expand the school practice, such as study tours, public service activities, volunteer activities, activities in the countryside, social labor and practice, which will help to enhance students' sense of social responsibility of citizens, citizens' sense of social responsibility education is a form of education, and actively carry out rich and colorful school practice. Not only meet the needs of the new era of ideological and political education and college students' physical and mental development, but also an effective way to enhance minority college students' sense of social responsibility.

\section{Teaching subject: to improve the situation and policy, the quality of teachers.}

We should strengthen the construction of teachers in colleges and universities, it should be in accordance with the channel organization, subject teaching ideas to establish a full-time teachers, the staff of ideological and political education as the combination of full-time and part-time teachers, channel organization, which fully exert a wide range of disciplines, teachers of the advantages of rich resources, hire experts other subjects to supplement the situation and policy class teachers; subject teaching according to the professional characteristics and research direction of the teacher, the course is divided into a number of different topics, teachers are responsible for different topics, teaching resources to achieve complementary advantages.

Pay attention to teachers' training work, organize teachers to participate in training, organize the teachers to carry out the social practice and investigation, and actively carry out scientific research and to encourage teachers, improve the teachers' occupation quality and scientific research ability.

Teachers should pay attention to the quality of training, teachers should carefully design and organize teaching activities, to achieve a good interaction in the classroom teaching process, use plain language, vivid examples, novel and lively form, the starting point for the classroom teaching of the butterfly effect, active teaching atmosphere, inspire students to think. At the same time, teachers should also keep pace with the times, to expand their own knowledge, make full use of the internet information dissemination channels, timely understanding of major events at home and abroad, and pay attention to the ideological trend of the students. 


\section{Teaching guarantee: optimizing policy and system mechanism to enhance the actual effect of situation and policy.}

Firstly, colleges and universities should conscientiously implement the opinions and notice. The spirit of the documents from country are to strengthen the education of situation and policy leadership, strengthen the education and teaching supervision, to standardize and improve the teaching management of colleges and universities, the establishment of the situation and policy teaching work leading group, responsible for the teaching of situation and policy planning, guidance and coordination of various departments, to enhance the efficiency of course.

Secondly, according to the average per semester for 16 weeks, 1 hour a week, 2 credits; specialist during the study, 1 credit's requirements, open enough hours, give enough credits.

Thirdly, fully consider the particularity of the situation and policy education and curriculum teaching, combined with the domestic and international situation, combined with the actual local economic and social development as well as the school, students' actual situation, with mining and combing the situation and policy education, establish the basic modes of situation and policy of civic education, effective way to improve the curriculum.

\section{Conclusion}

The course situation and policy in colleges and universities bears the responsibility of cultivating college students' sense of social responsibility. In view of the current curriculum, nurturing minority college students' social responsibility awareness problems, and closely combine the ideological reality of college students, improve the situation and policy curriculum construction is particularly important. The teaching way should construct students' subjective teaching mode, arouse the consciousness of college students' social responsibility, combine theory teaching with social practice, and urge university students to abandon the idea of not present.

\section{Acknowledgement}

The work was supported by Jiangxi province college of humanities and social sciences subject: "comprehensive research on cultivating the sense of the rule of law under the background of minority college students' social responsibility" (project number: MKS161013) one sub project: Nanchang institute of humanities and social sciences subject: "in order to enhance the students' sense of social responsibility to guide the course of situation and policy teaching reform -- a case of Nanchang Institute of technology " (project number: GJRW - 16 - 18) of the research results.

\section{References}

[1] Zhang Y B. Frontier practice of functional movement training in competitive sports[J]. Shandong Sports Science \& Technology, 2012.

[2] Luo M, Tu Y. Application of Trimp in Training Monitoring of Competitive Sports[J]. Open Cybernetics \& Systemics Journal, 2015, 9(1):2463-2466.

[3] Zhang Y. Stability and Mobility in Human Movement Patterns[J]. China Sports Coaches, 2012.

[4] Yan-Ling L I. On the functions of market to the operation of Competitive Sports[J]. Journal of Educational Science of Hunan Normal University, 2002.

[5] Tang Q, Bian B, Zhu N, et al. The Application of Training Impulse (TRIMP) in Marathon 
Training Load Monitoring[J]. Sports \& Science, 2013.

[6] Zhu N, Sheng L, Cao P. The Application on Trimp in Sports Monitoring[J]. Journal of Sports \& Science, 2011.8.

[7] Foster C, Florhaug J A, Franklin J, et al. A new approach to monitoring exercise training.[J]. Journal of Strength \& Conditioning Research, 2001, 15(1):109-115. 